Supporting Information

\title{
Thermally Stable and Solvent-Resistant
}

\section{Conductive Polymer Composites with Cross-linked Siloxane Network}

Zhifan Ke, Liyan You, Dung T. Tran, Jiazhi He, Kuluni Perera, Aristide Gumyusenge, Jianguo $\mathrm{Mei}^{*}$

560 Oval Drive, Purdue University, West Lafayette, IN 47907, USA

*E-mail: jgmei@purdue.edu 


\section{S1. Synthetic Protocols and ${ }^{1}$ H NMR spectrum}

1.1 Synthetic Protocols
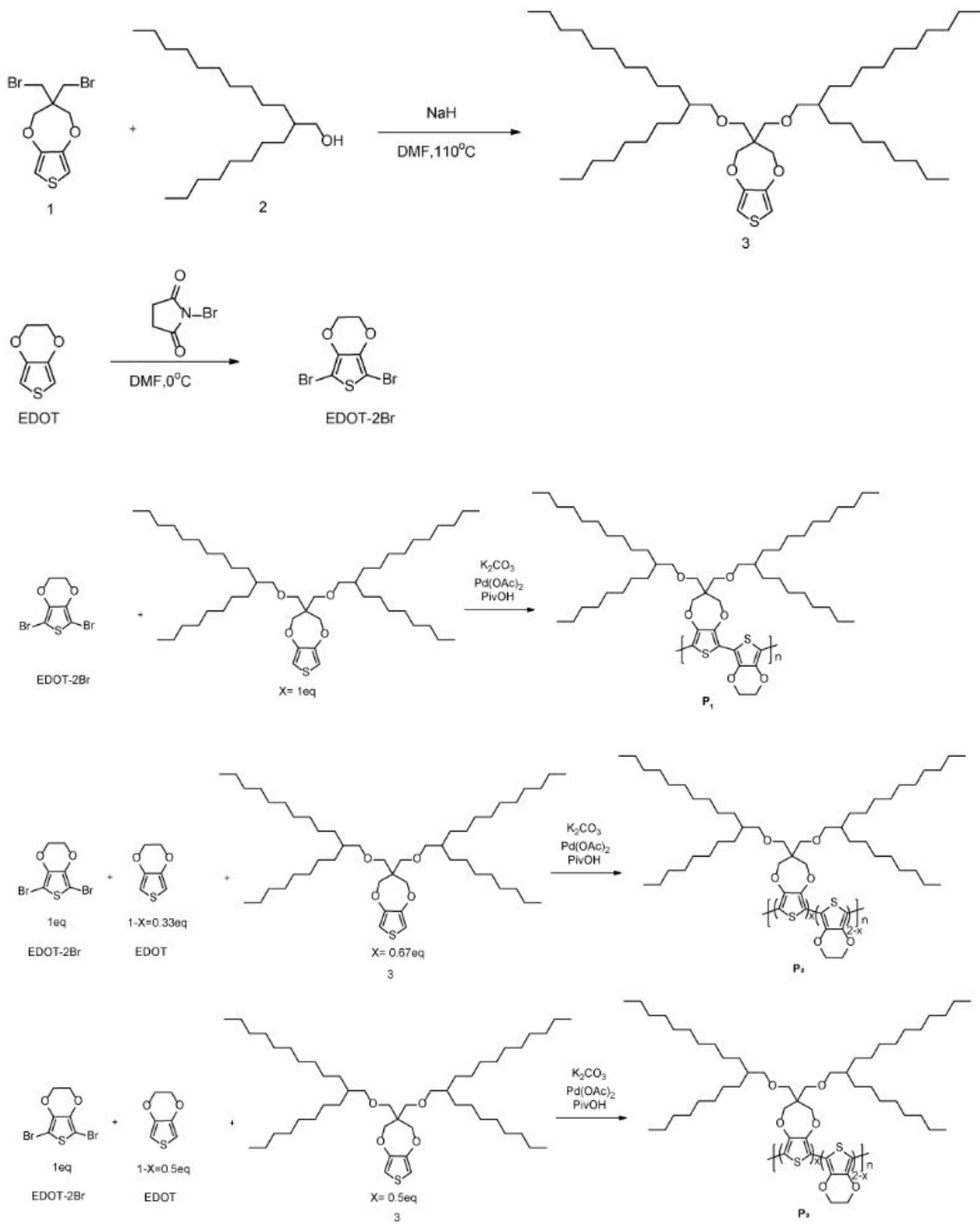

Scheme S1. Synthetic routes for compound $\mathrm{P}_{1}, \mathrm{P}_{2}, \mathrm{P}_{3}$

(Compound 3): To a $1000 \mathrm{~mL}$ flask was charged with a stir bar, 2-Octyl-1-dodecanol (compound 2, $31.4 \mathrm{~g}, 105.2 \mathrm{mmol}$ ) and DMF 180mL. 60\% NaH (4 g, $101 \mathrm{mmol}$ ) was added slowly, then heat the mixture to $100{ }^{\circ} \mathrm{C}$ for $20 \mathrm{~min}$. After cool to room temperature added 3,3bis(bromomethyl)-3,4-dihydro-2H-thieno[3,4-b][1,4]dioxepine (compound 1, 15g, 43.9 $\mathrm{mmol}$ ) and heat to $110{ }^{\circ} \mathrm{C}$ reacted for $18 \mathrm{~h}$. Then cool to room temperature and added $540 \mathrm{~mL}$ water and $300 \mathrm{~mL}$ hexane to extract the product. The hexane layer was collected and rotovap to remove solvent then submitted to silica gel column to purify compound 3. Colorless oil $20 \mathrm{~g}$ was got. $(\mathrm{Y}=60 \%)$.

${ }^{1} \mathrm{H}$ NMR (300 MHz, $\left.\mathrm{CDCl}_{3}\right) \delta(\mathrm{ppm}): 6.43$ (s, 2H), $4.00(\mathrm{~s}, 4 \mathrm{H}), 3.45$ (s, 4H), $3.26(\mathrm{~d}, 4 \mathrm{H}$, $\mathrm{J}=6 \mathrm{~Hz}), 1.26-0.86(\mathrm{~m}, 78 \mathrm{H})$. 


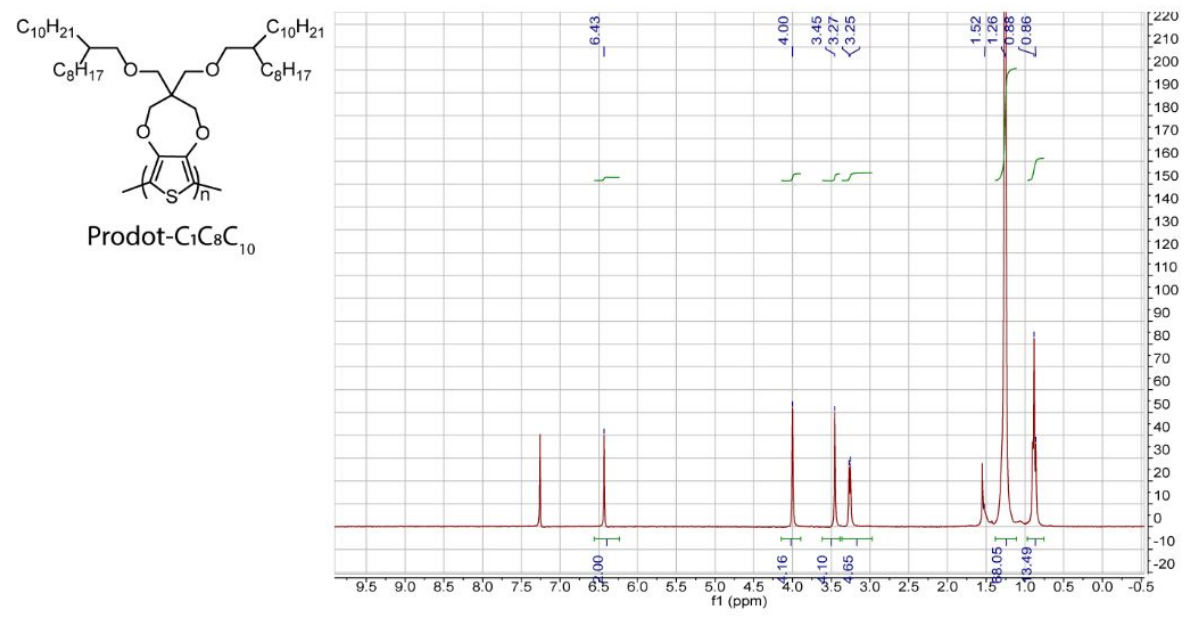

Figure S1. ${ }^{1} \mathrm{H}$ NMR spectrum of compound 3.

(EDOT-2Br): To a $500 \mathrm{~mL}$ flask was charged with a stir bar, EDOT (4.0 g, $28 \mathrm{mmol}$ ) and DMF $20 \mathrm{~mL}$ then cool to $0^{\circ} \mathrm{C}$. NBS $(10.5 \mathrm{~g}, 59 \mathrm{mmol})$ was dissolved into $50 \mathrm{~mL}$ DMF and added into the flask dropwise. After stir at $0^{\circ} \mathrm{C}$ for $50 \mathrm{~min} 100 \mathrm{~mL}$ water was added into the flask. Filter and wash with $\mathrm{MeOH} /$ water $=1 / 2$ solution $50 \mathrm{~mL}$ to get white solid $8 \mathrm{~g}(95 \%)$.

${ }^{1} \mathrm{H}$ NMR $\left(300 \mathrm{MHz}, \mathrm{CDCl}_{3}\right) \delta(\mathrm{ppm}): 4.27(\mathrm{~s}, 4 \mathrm{H})$.

(Polymer $\mathbf{P}_{1}$ ): To a Schlenk tube charged with a stir bar, compound 3 ( $0.777 \mathrm{~g}, 1.0 \mathrm{mmol}$ ), EDOT-2Br ( $0.3 \mathrm{~g}, 1.0 \mathrm{mmol}$ ), PivOH ( $31 \mathrm{mg}, 0.3 \mathrm{mmol}), \mathrm{Pd}(\mathrm{OAc})_{2}$ ( $4.5 \mathrm{mg}, 0.02 \mathrm{mmol}$ ) and $\mathrm{K}_{2} \mathrm{CO}_{3}(0.36 \mathrm{~g}, 2.6 \mathrm{mmol})$. The mixture was vacuum and refilled with nitrogen for three times. Degas DMAc $8 \mathrm{~mL}$ was added with syringe and heat to $140^{\circ} \mathrm{C}$ for $18 \mathrm{~h}$. Then precipitate the solution with $100 \mathrm{~mL}$ methanol. Filter and washed with methanol to get solid. The solid was dissolved into $30 \mathrm{~mL}$ chloroform, $0.5 \mathrm{~mL}$ of hydrazine hydrate was added and stirred for $20 \mathrm{~min}$. The solution was washed with $30 \mathrm{~mL} 1 \mathrm{~N} \mathrm{HCl}$ twice, then washed with 30 $\mathrm{mL}$ DI water. The solution was added into $200 \mathrm{~mL}$ methanol and precipitate the polymer. Solid precipitate from the solution was filter and dry to get the desired polymer. $(0.76 \mathrm{~g}$, $\mathrm{Y}=83 \%)$

${ }^{1} \mathrm{H}$ NMR (300 MHz, $\left.\mathrm{CDCl}_{3}\right) \delta(\mathrm{ppm}): 4.38-3.94(\mathrm{~m}, 4 \mathrm{H}), 3.64-3.5(\mathrm{~m}, 12 \mathrm{H}), 1.79-0.83(\mathrm{~m}$, $78 \mathrm{H})$. 


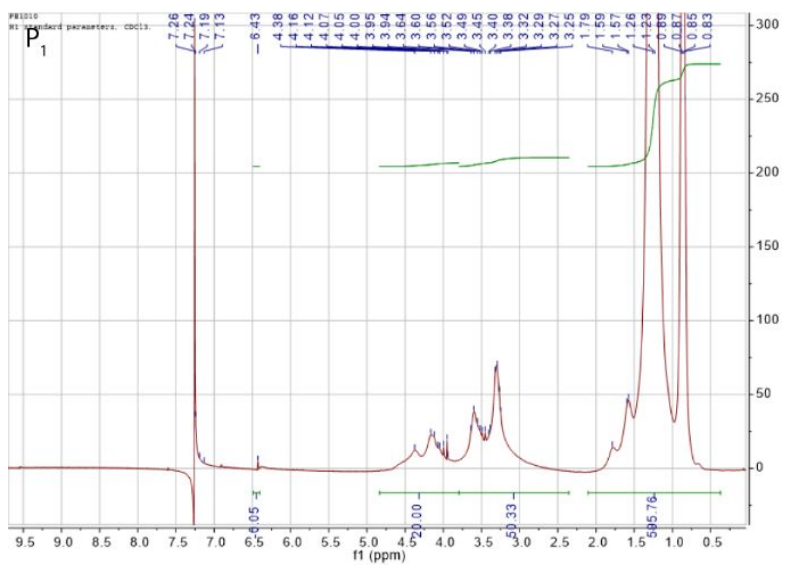

Figure S2. ${ }^{1} \mathrm{H}$ NMR spectrum of $\mathrm{P}_{1}$.

(Polymer $\mathbf{P}_{2}$ ): To a Schlenk tube charged with a stir bar, compound $3(0.521 \mathrm{~g}, 0.67 \mathrm{mmol})$, EDOT-2Br ( $0.3 \mathrm{~g}, 1.0 \mathrm{mmol}$ ), EDOT ( $0.047 \mathrm{~g}, 0.33 \mathrm{mmol}$ ), PivOH ( $31 \mathrm{mg}, 0.3 \mathrm{mmol}$ ), $\mathrm{Pd}(\mathrm{OAc})_{2}(4.5 \mathrm{mg}, 0.02 \mathrm{mmol})$ and $\mathrm{K}_{2} \mathrm{CO}_{3}(0.36 \mathrm{~g}, 2.6 \mathrm{mmol})$. The mixture was vacuum and refilled with nitrogen for three times. Degas DMAc $8 \mathrm{~mL}$ was added with syringe and heat to $140{ }^{\circ} \mathrm{C}$ for $18 \mathrm{~h}$. Then precipitate the solution with $100 \mathrm{~mL}$ methanol. Filter and washed with methanol to get solid. The solid was dissolved into $30 \mathrm{~mL}$ chloroform, $0.5 \mathrm{~mL}$ of hydrazine hydrate was added and stirred for 20min. The solution was washed with $30 \mathrm{~mL} 1 \mathrm{~N} \mathrm{HCl}$ twice, then washed with $30 \mathrm{~mL}$ DI water. The solution was added into $200 \mathrm{~mL}$ methanol and precipitate the polymer. Solid precipitate from the solution was filter and dry to get the desired polymer. $(0.59 \mathrm{~g}, \mathrm{Y}=88 \%)$.

${ }^{1} \mathrm{H}$ NMR (300 MHz, $\left.\mathrm{CDCl}_{3}\right) \delta(\mathrm{ppm}): 4.90-3.90(\mathrm{~m}, 8 \mathrm{H}), 3.59-3.25$ (m, 12H), 1.45-0.75 (m, $78 \mathrm{H})$.

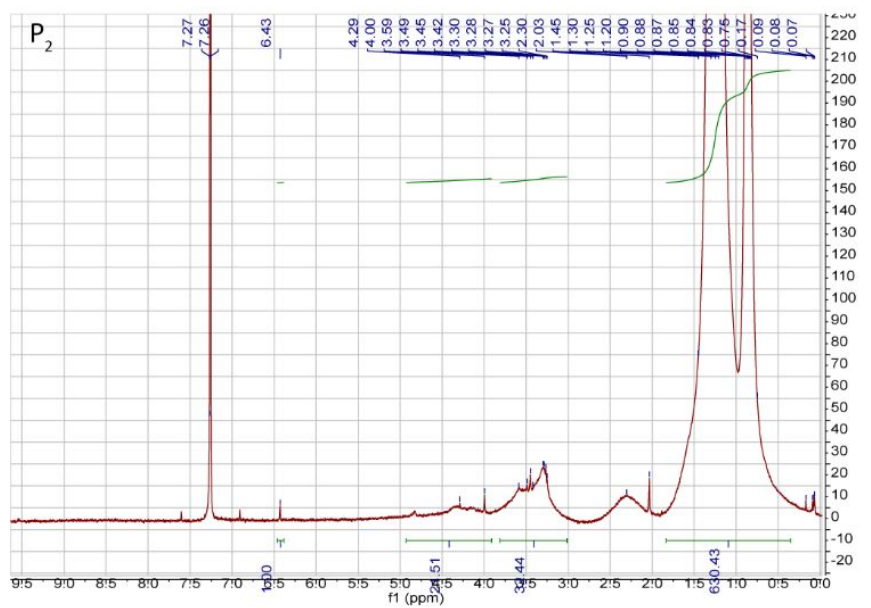

Figure S3. ${ }^{1} \mathrm{H}$ NMR spectrum of $\mathrm{P}_{2}$.

(Polymer $\mathbf{P}_{\mathbf{3}}$ ): To a Schlenk tube charged with a stir bar, compound 3 ( $0.518 \mathrm{~g}, 0.67 \mathrm{mmol}$ ), EDOT-2Br ( 0.4 g, $1.33 \mathrm{mmol}$ ), EDOT ( $0.095 \mathrm{~g}, 0.67 \mathrm{mmol}$ ), PivOH ( $41 \mathrm{mg}, 0.4 \mathrm{mmol}$ ), $\mathrm{Pd}(\mathrm{OAc})_{2}(6.0 \mathrm{mg}, 0.027 \mathrm{mmol})$ and $\mathrm{K}_{2} \mathrm{CO}_{3}(0.48 \mathrm{~g}, 3.5 \mathrm{mmol})$. The mixture was vacuum and refilled with nitrogen for three times. Degas DMAc $8 \mathrm{~mL}$ was added with syringe and heat to $140^{\circ} \mathrm{C}$ for $18 \mathrm{~h}$. Then precipitate the solution with $100 \mathrm{~mL}$ methanol. Filter and washed with methanol to get solid. The solid was dissolved into $50 \mathrm{~mL}$ chloroform, $0.5 \mathrm{~mL}$ of hydrazine hydrate was added and stirred for $20 \mathrm{~min}$. The solution was washed with $40 \mathrm{~mL} 1 \mathrm{~N}$ $\mathrm{HCl}$ twice, then washed with $40 \mathrm{~mL}$ DI water. The solution was added into $250 \mathrm{~mL}$ methanol 
and precipitate the polymer. Solid precipitate from the solution was filter and dry to get the desired polymer. $(0.57 \mathrm{~g}, \mathrm{Y}=80 \%)$

${ }^{1} \mathrm{H}$ NMR (300 MHz, $\left.\mathrm{CDCl}_{3}\right) \delta(\mathrm{ppm}): 4.38-3.95$ (m, 12H), 3.58-3.27 (m, 12H), 1.30-0.83 (m, $78 \mathrm{H})$.

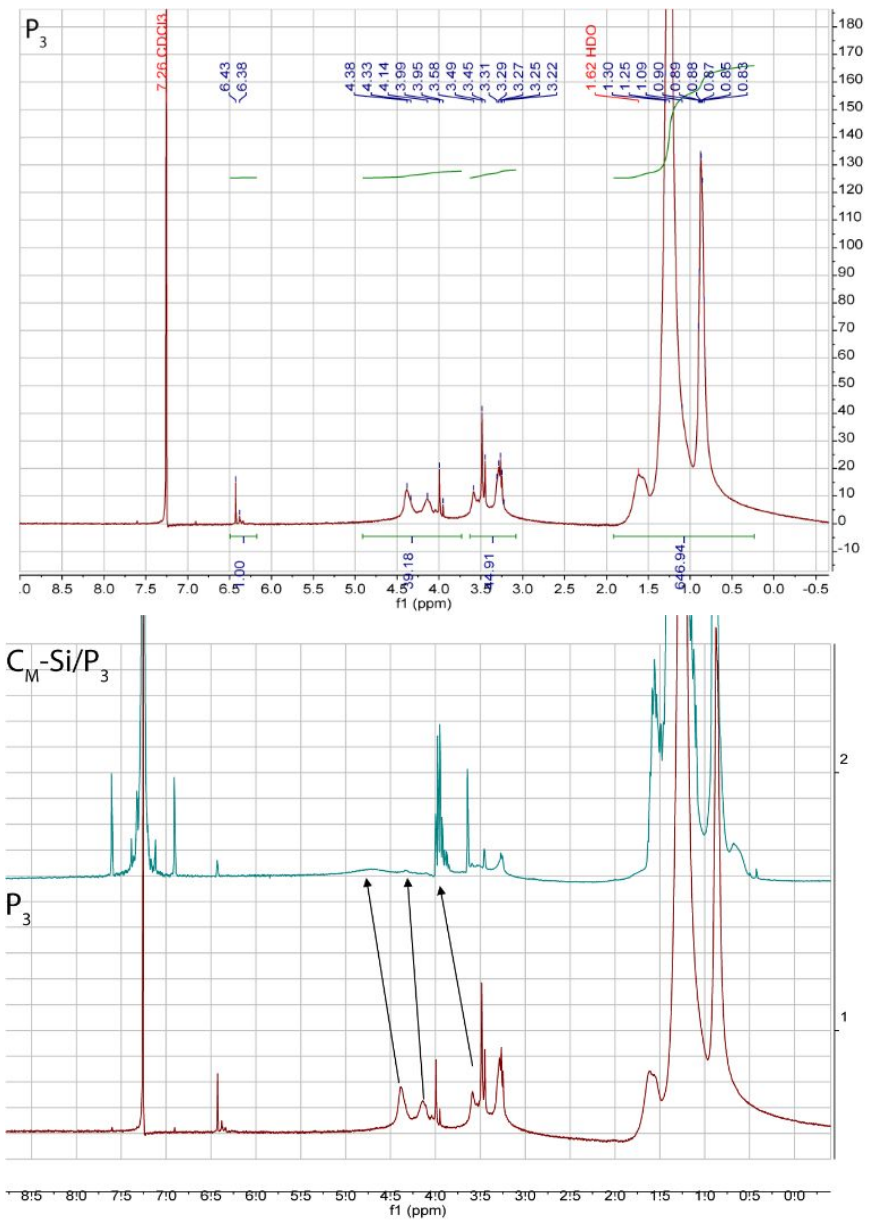

Figure S3. ${ }^{1} \mathrm{H}$ NMR spectrum of $\mathrm{P}_{3}$ and $\mathrm{C}_{\mathrm{M}^{-}} \mathrm{Si} / \mathrm{P}_{3}$.

\section{S2. Additional Tables, Schemes and Figures}

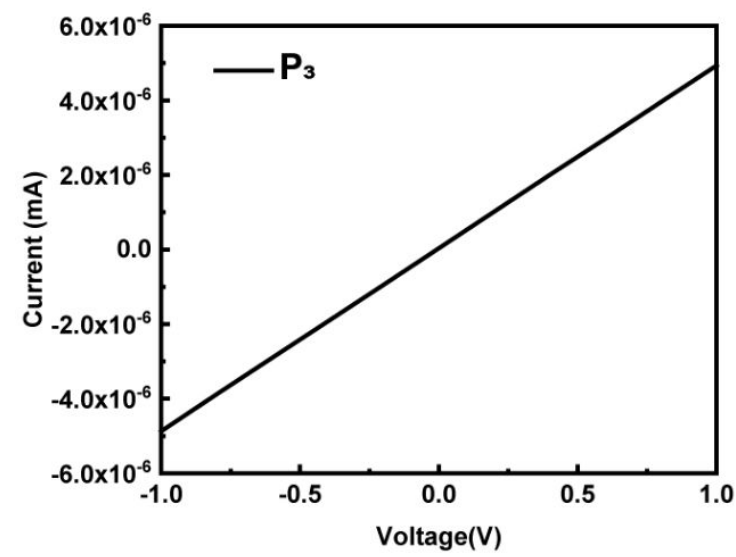

Figure S4 I-V curve of pure $\mathrm{P}_{3}$. 

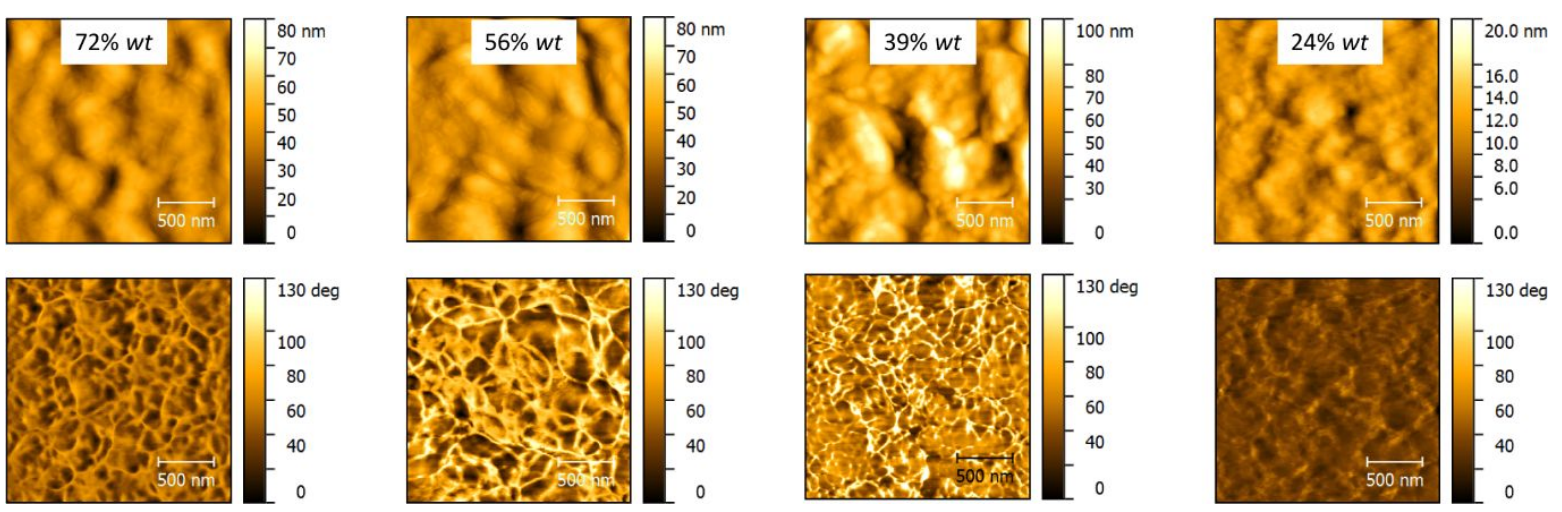

Figure S5 AFM height and phase images of $\mathrm{C}_{6}-\mathrm{Si} / \mathrm{P}_{3}$ composites with different content of $\mathrm{C}_{6^{-}}$ Si.

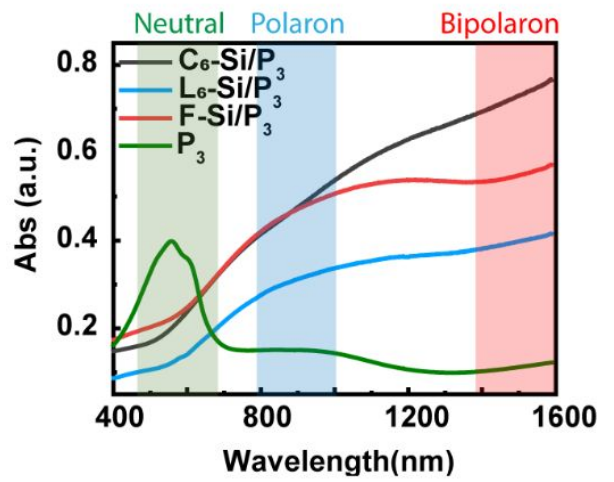

Figure S6 Thin films UV-Vis spectra of pure $\mathrm{P}_{3}$ and different chlorosilanes/ $\mathrm{P} 3$ composites at $56 \%$ $w t$ of the dopants.

Pure $\mathrm{P}_{3}$

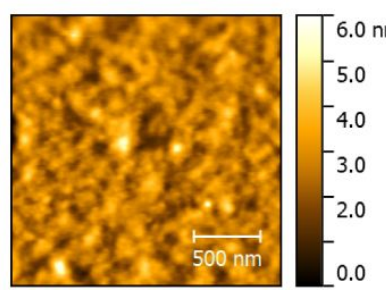

$\mathrm{C}_{6}-\mathrm{Si}_{\mathrm{P}} / \mathrm{P}_{3}$

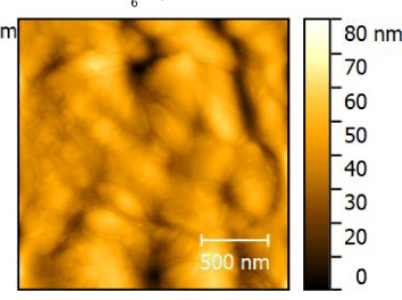

Figure S7 AFM height images of pure $\mathrm{P}_{3}$ and $56 \%$ wt $\mathrm{C}_{6}-\mathrm{Si} / \mathrm{P}_{3}$.
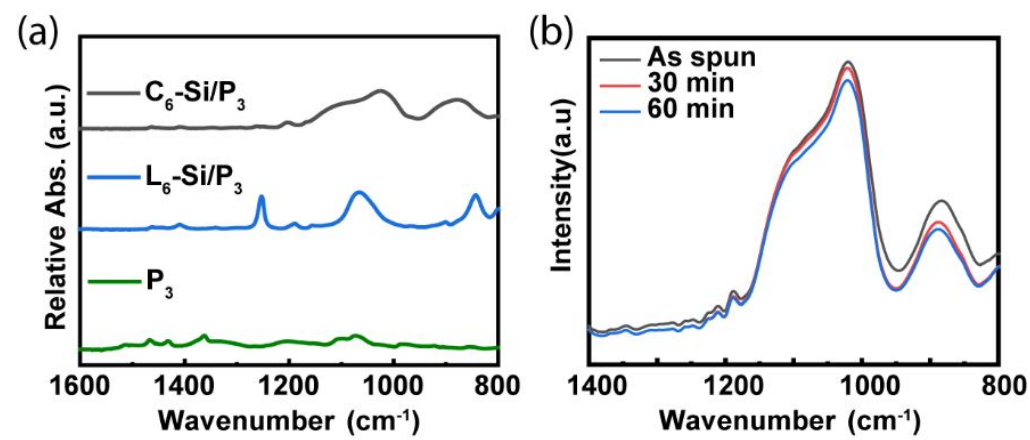

Figure S8 (a) FTIR spectrum of pure $\mathrm{P}_{3}, \mathrm{C}_{6}-\mathrm{Si} / \mathrm{P}_{3}$ and $\mathrm{L} 6-\mathrm{Si} / \mathrm{P}_{3}$ composites with $56 \%$ wt of chlorosilanes; (b) FTIR spectrum of $56 \%$ wt $\mathrm{C}_{6}-\mathrm{Si} / \mathrm{P}_{3}$ composites before and after annealing at $393 \mathrm{~K}$. 
(a)

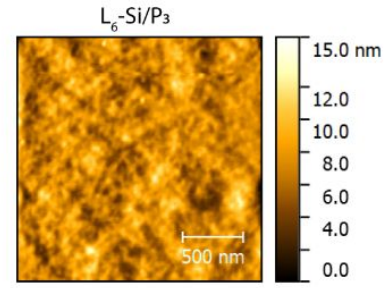

(b)

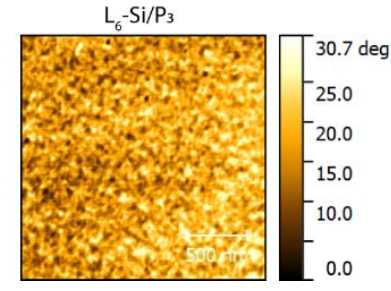

$\mathrm{F}-\mathrm{Si} / \mathrm{P}_{3}$

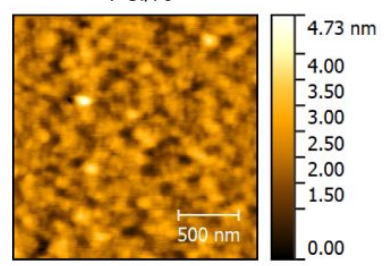

$\mathrm{F}-\mathrm{Si} / \mathrm{P}_{3}$

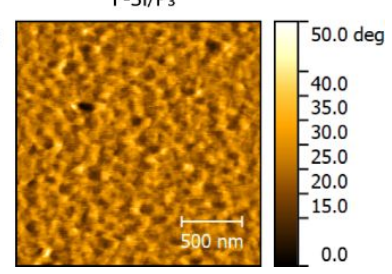

Figure S9 AFM height images a) and phase images b) of $56 \% w t \mathrm{~L}_{6}-\mathrm{Si} / \mathrm{P}_{3}$ and $56 \% w t \mathrm{~F}$ $\mathrm{Si} / \mathrm{P}_{3}$.
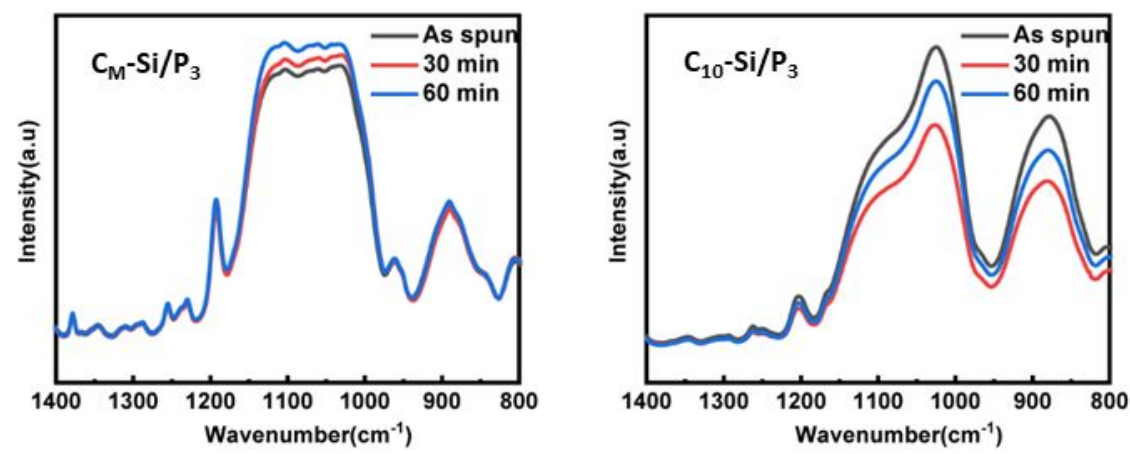

Figure S10 FTIR spectrum of $56 \%$ wt $\mathrm{C}_{\mathrm{M}^{-}} \mathrm{Si} / \mathrm{P}_{3}$ composites and $\mathrm{C}_{10}-\mathrm{Si} / \mathrm{P}_{3}$ before and after annealing at $393 \mathrm{~K}$.
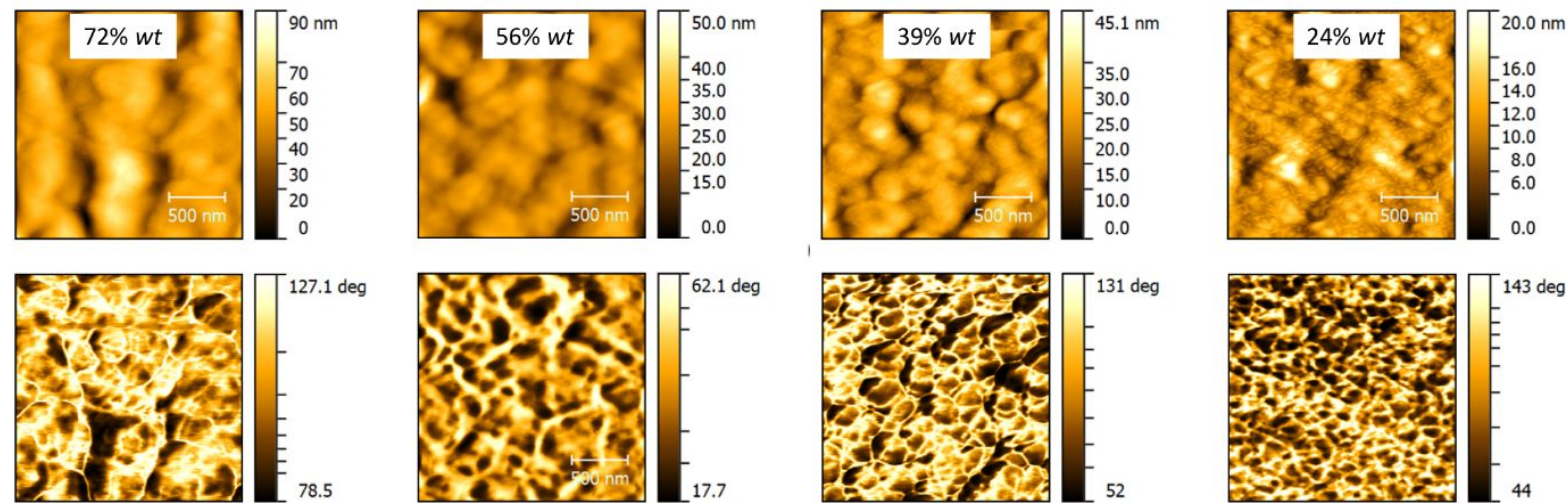

Figure S11 AFM height and phase images of $\mathrm{C}_{\mathrm{M}}-\mathrm{Si} / \mathrm{P}_{3}$ composites with different content of $\mathrm{C}_{\mathrm{M}}-\mathrm{Si}$. 


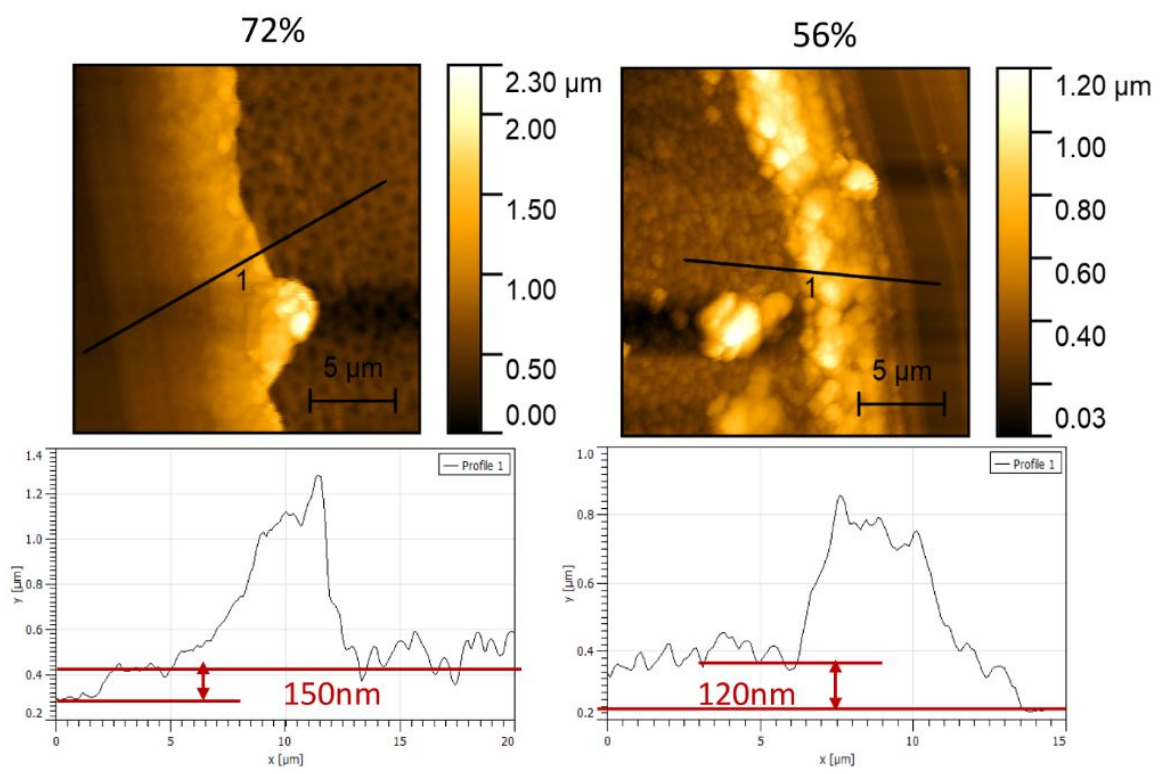

Figure S12 Film thickness of $\mathrm{C}_{\mathrm{M}^{-}} \mathrm{Si} / \mathrm{P}_{3}$ composites with different content of $\mathrm{C}_{\mathrm{M}^{-}} \mathrm{Si}$.

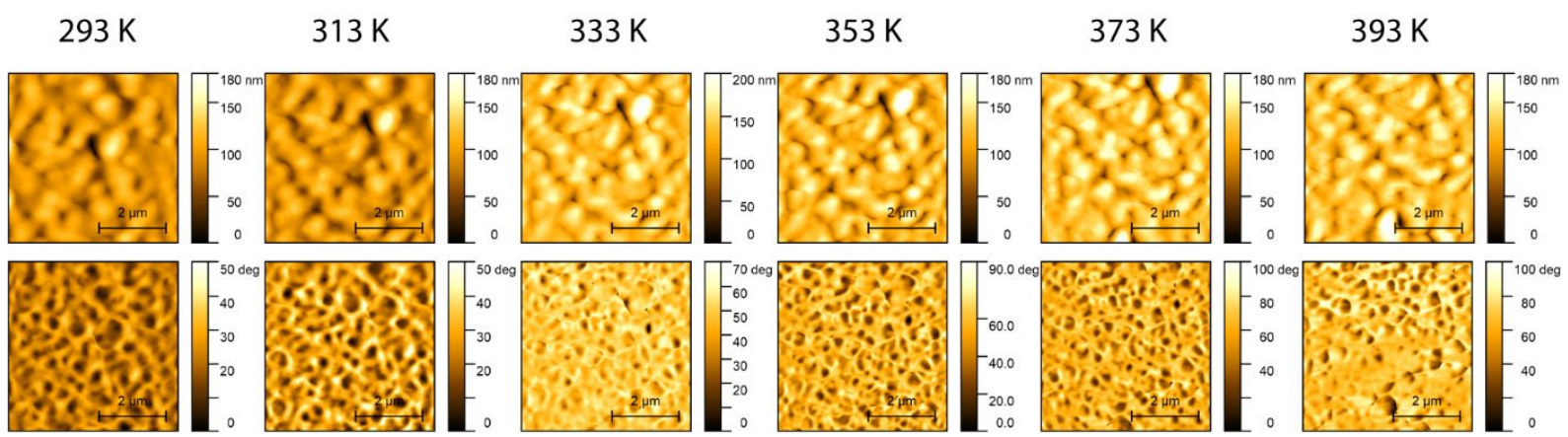

Figure S13 In-suit temperature dependent AFM height and phase images of $\mathrm{C}_{\mathrm{M}}-\mathrm{Si} / \mathrm{P}_{3}$ composites when increasing temperature from $293 \mathrm{~K}$ to $393 \mathrm{~K}$.

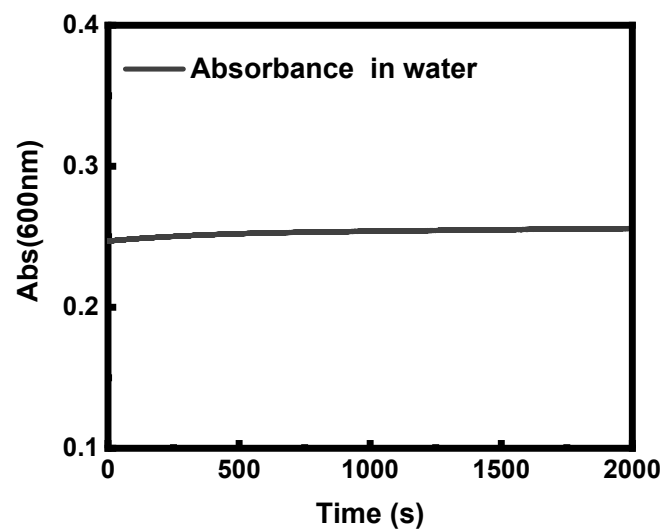

Figure S14 In-suit UV-Vis absorption at $600 \mathrm{~nm}$ of $\mathrm{C}_{\mathrm{M}^{-}} \mathrm{Si} / \mathrm{P}_{3}$ composites in the water. 
(a)

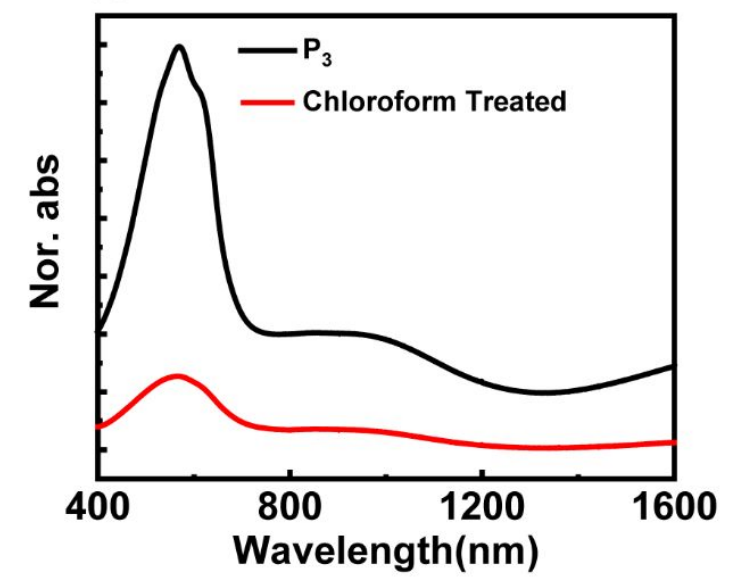

(b)

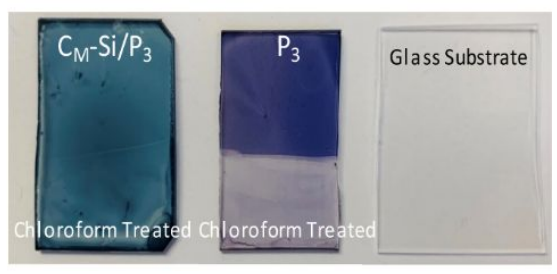

Figure S15 a) UV-Vis absorptions of pure $\mathrm{P}_{3}$ film before and after being dipped in

chloroform; b) photos of $56 w t \% \mathrm{C}_{\mathrm{M}}-\mathrm{Si} / \mathrm{P}_{3}$ composites and pure $\mathrm{P}_{3}$ film before and after being dipped in chloroform.

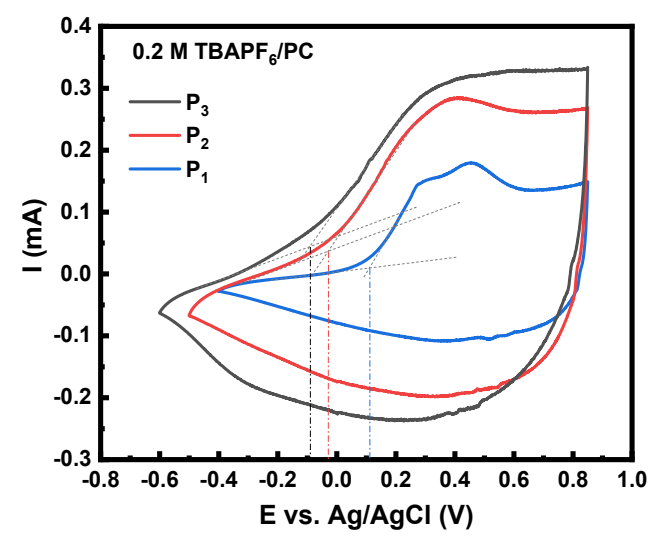

Figure S16 Cyclic voltammetry (CV) of pure CPs in $0.2 \mathrm{M}$ tetrabutylammonium hexafluorophosphate $\left(\mathrm{TBAPF}_{6}\right)$ in propylene carbonate $(\mathrm{PC})$ recorded at a scan rate of $40 \mathrm{mV}$ $\mathrm{s}^{-1}$. The oxidation potential of $\mathrm{P}_{3}, \mathrm{P}_{2}$ and $\mathrm{P}_{1}$ is around $-0.1 \mathrm{~V},-0.02 \mathrm{~V}$ and $0.1 \mathrm{~V}$, respectively.

(a)

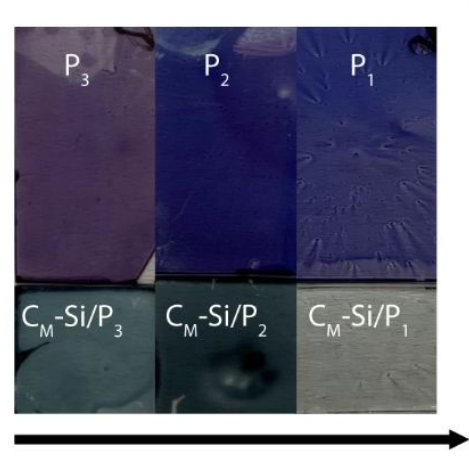

Oxidation Potential Level

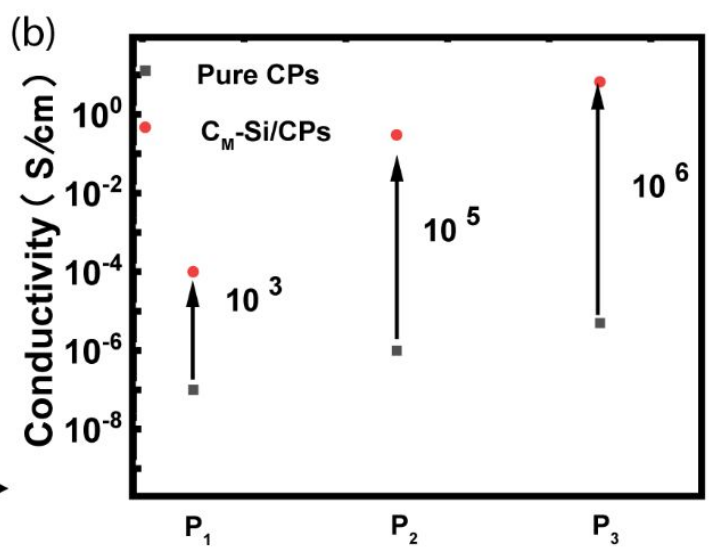

Figure $\mathrm{S17}$ a) Photographs of CPs films and $\mathrm{C}_{\mathrm{M}^{-}} \mathrm{Si} / \mathrm{CPs}$ composites; b) conductivity comparison of CPs films and $\mathrm{C}_{\mathrm{M}}-\mathrm{Si} / \mathrm{CPs}$ composites. 


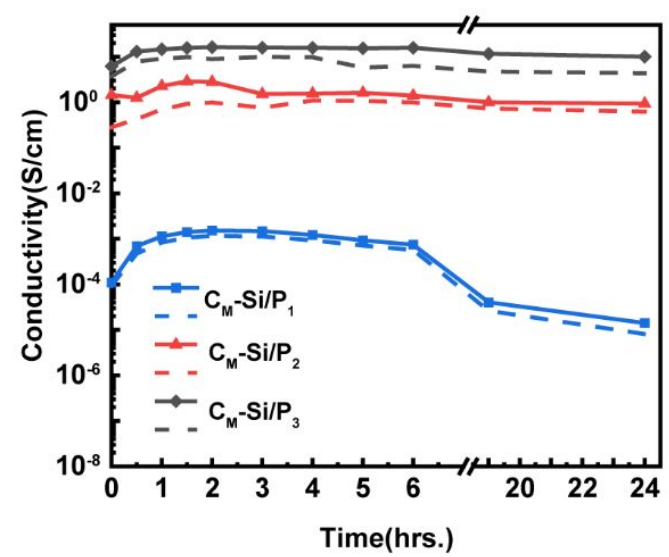

Figure S18 Conductivities of $56 w t \% \mathrm{C}_{\mathrm{M}^{-}} \mathrm{Si} / \mathrm{CPs}$ composites with different $\mathrm{CPs}$ when baked at $353 \mathrm{~K}$ under ambient conditions after 24 hours, measured by two-probe and four. The lines with symbols refer to the result measured by two-probe method and the dashed lines refer to four-probe method results. 